\title{
COMMENSALITY AND INDIVIDUAL EATING: MEDIATING SOCIAL RELATIONSHIPS DURING WORK BREAKS
}

\section{Irma Šidiškiene}

Researcher at the Lithuanian Institute of History, Department of Ethnology and Anthropology

E-mail: irma.sidiskiene@istorija.lt

\begin{abstract}
Based on an analysis of eating during work hours, this article looks at the issue of maintaining informal social relations. Various forms of the gathering together of individuals are important in the maintenance of social relations. Very often, casual or leisure-time gatherings, whether they are to mark an important event or celebration, or are just a coffee or lunch break during work hours, involve eating or drinking. However, colleagues and co-workers do not always eat at the same time, especially regarding day-to-day eating during work hours. In this paper, the focus is on the relative importance of eating alone or eating in a group when researching the maintenance of informal relations. The first objective of this research is to clarify the social aspects in research on eating and to survey the scientific literature on commensality and eating alone. Second the paper looks at how eating in a group as opposed to individual eating are expressed as part of the daily eating routine with ones co-workers. By going through these objectives, the question is raised - how would ways of maintaining informal relations change if there an ever greater number of co-workers decided to eat alone?
\end{abstract}

Keywords: co-workers; daily eating; celebration-based eating; commensality with co-workers; individual eating in public places; informal social relations 


\section{Introduction}

Various forms of gathering among co-workers are important in the maintenance of social relations. Diet, eating, snacking or having drinks (for the purposes of clarity in this article, all of these activities will be referred to as eating) ${ }^{1}$ at work or during work breaks is an inseparable part of daily culture, and is one of the more important times in the organization of work and in the gathering together of co-workers in their leisure time. Gatherings to mark various celebrations are one of the most conducive ways of establishing and maintaining informal social links with co-workers, often in a wider circle. In a narrower circle, for example, of several co-workers who share the same office space and have friendly relations, such links are maintained on a daily basis when drinking coffee or tea together, or going for lunch. Thus, eating together is conducive to facilitating informal relations. In this article, based on an analysis of eating during work hours, the issue of maintaining informal social relations will be analysed.

Only a handful of studies have been conducted in Lithuanian ethnology to date where social relations between co-workers have been the topic of analysis. These includes studies of collective help (Lith. - talka, communal work for the benefit of a group or family) in Lithuania in the late nineteenth to twentieth centuries. As Liudvikas Nezabitauskis wrote, 'The finest and most distinctive cooperation among our village populations emerged during talka (collective help), an expression conveying a clear sense of good neighbourly relations' (Nezabitauskis 1935: 113, 115). In terms of social relations, Nezabitauskis comment that it was neighbours and relatives who felt 'amicability' towards one another who would join in talka (collective help) is important (ibid.: 114). Although research on collective help in Lithuania has covered various fields, ${ }^{2}$ for the purposes of this topic of research what is significant is the comment that one of the more important highlights of these collective aid events was the food that would be shared during them. ${ }^{3}$ This significance is also evident in my earlier article, 'Neformalių kaimo ir miesto darbo bendrijų sąsajos socialinių santykių aspektu' (The Relationship between Informal Rural and Urban Communities in the Aspect of Social Relations; Šidiškienè 2017). Based on ethnologists' studies of such collective help, that earlier article explained how general social value was created during collective help events in village communities in Lithuania in the late nineteenth and first half of the twentieth century. Among various other factors, one of the stimuli for participating in this collective help was the eating or sharing of food that went along with it (meant here in the etic sense). 
In order to compare and seek out similarities between such work groups and those formed by urban co-workers in the second half of the twentieth and early 21 st centuries, the statements of respondents in Vilnius were used to explain what, in their terms, constituted a group of co-workers. In the emic sense, it was found that, as an important stimulus for them to gather together and stay together, food (feasting) was not actually stressed, though it was mentioned (Šidiškienè 2017: 87, 90).

When analysing the leisure time and celebrations of co-workers in Vilnius, it became apparent that one of the most productive times for establishing and maintaining informal social links was the celebration of various occasions (Šidiškienè 2019b). One of the more important elements of gatherings outside of work hours was sitting down at a table together to eat. Brought food and drink, as well as gifts, were a constant accompaniment of personal celebrations among co-workers (Šidiškienè 2019b: 126). It is not surprising to find Chloe Nahum-Claudel summarizing the situation as follows: 'feasting invariably transcends the social, and eating and drinking appear to be particularly powerful mediums through which to attempt to exert control over invisible agencies that encompass human life - be it the state, the feudal order, the ecology, or the spirits and ancestors who determine life and death' (Nahum-Claudel 2016: 14). At workplaces, official celebrations are marked formally, some involving feasting, some being paid for, at least partly, out of the organisation's funds, but usually marked informally with food and drink that the employees had brought themselves to share with everyone (Šidiškienè 2018, 2019a, 2019b). However, the daily coffee or tea breaks of co-workers, or their having lunch, could either take place with other co-workers, or could be individual acts. Unlike on special occasions, the daily gathering of co-workers to eat takes place amid a smaller group than during celebrations.

This discussion raises the importance of eating together or commensality ${ }^{4}$ versus eating individually when researching the maintenance of informal social relations. Neither eating together with others nor eating alone make direct references to the maintenance or otherwise of social relations, which is why, when researching informal relations, it is important to draw attention to both circumstances. The first objective of this research was to clarify the social aspect of research on eating, looking at the literature on commensality and individual eating. Having reviewed the research about eating with co-workers, the second objective was to expand it by including the case of daily eating among co- 
workers in Vilnius. Analysis of the problem, observation and semi-structured interviews were the methods used in this research. ${ }^{5}$

\section{The social aspect of commensality research}

Commensality has received the attention of scholars from various disciplines. Health researchers have, among other things, analysed various social circumstances (e.g., eating with friends, with strangers, with people of the opposite gender, etc. and alone) that may affect the quantity of food the individual consumes (Hetherington et al. 2006; see Polivy and Pliner 2015 for a wider review of the literature on this topic). Others have shown that social influence on eating habits is strong and spreading (Higgs and Thomas 2016), and that when comparing themselves to other eaters, individuals can alter not just how they feel but also how much they eat (Polivy 2017). It is important to note that these researchers also found that commensality is considered to be a universal intercultural human characteristic which encourages communication and feelings of happiness (Yiengprugsawan et al. 2015).

Sociologists and anthropologists also stress the importance of commensality from the perspective of social relations because, while eating with others, individual participants establish and rank social relations and connect with each other and with power structures, while also prompting collective understanding. Claude Grignon described commensality as a gathering aimed to accomplish collectively certain material tasks and symbolic obligations linked to the satisfaction of individual biological needs (Grignon 2001: 24). When analysing the phenomenon of commensality, it is important to take into account where it takes place, the time, and the group that are eating together. Grignon mentioned several types of commensality in his article. Firstly, he distinguished types according to place - domestic and institutional commensalities (other researchers also refer to the latter as public commensality, that is, eating in school, hospital, prison cafeterias and alike). Secondly, according to time, there is everyday and exceptional commensality. Third, according to group, there is segregative commensality (in a closed group) and transgressive commensality (involving others outside the group's boundaries) (Grignon 2001). In his view, some of these groups are incidental and superficial, others, conversely, are closely related to the very principles upon which society is organised. As we know, the family is considered the main cell of society, which is why most 
studies were conducted by analysing diet in the family, and less often in other sorts of groups.

Commensality and the sharing of food are endowed with social and cultural value in Western countries. ${ }^{6}$ Feasting, where there is eating and drinking together, is associated with fun and a festive mood. In turn, in a daily sense, conviviality is related to joyous gatherings, good company and feasting (Nowicka 2020: 20). Therefore, commensality (especially during celebrations, on special occasions) is often associated with happiness in the scholarly literature: 'Conviviality through eating together is the basis of commensality' (Tan 2015: 14). As already note, eating together, not just on special occasions but on a daily basis, arouses positive feelings, lifts the mood and creates pleasant memories about the gathering, etc. However, other studies have shown that conviviality should not be identified or confused with commensality. There are sometimes incidental, temporary, business-related or other occasions that are not necessarily pleasant but more of an obligation, yet they do calm a tense atmosphere, making it easier to reach a mutually beneficial agreement. A number of studies have highlighted the positive influence of treating business partners to free lunches and dinners on the ability to reach favourable agreements (Spence 2016). Commensality studies have also revealed that sharing meals is can also be stressful for the participants. These negative feelings may encourage young adults to choose to eat alone from time to time or to make adjustments to commensal eating events (Danesi 2012).

When researching commensality from the perspective of social relations, time is very important, i.e., everyday commensality versus the commensality of exceptional occasions. Feasting organized for celebrations has attracted the broad attention of social-science researchers, who have analysed them from the perspective of their function in establishing exchange relations, social hierarchies and the sense of belonging to a group. Arnold van Gennep noted: 'The rite of eating and drinking together ... is clearly a rite of incorporation, of physical union, and has been called a sacrament of communion. A union by this means may be permanent, but more often it lasts only during the period of digestion' (Van Gennep 1960: 29). In other works, we can see how 'The table of the feast becomes a physical and symbolic place, where social inclusion and exclusion are exercised and power hierarchies are played out' (Montanari 1992, citing Marovelli 2019: 192). Researching everyday commensality from its social aspect has highlighted changes to this phenomenon, where not only 
the commensality model has changed but also who participates, the frequency and also the method: eating on the run, in the car, and the consumption of fast food more generally have become widespread. Eating has increasingly become an individual affair in Western countries. A comparative study on 'Associations between meal complexity and social context in four Nordic countries' showed that daily lunches and dinners differed: lunches were most often eaten either alone or with colleagues. Norwegians and Danes had lunch alone more often than Finns and Swedes. In Sweden dinners were eaten slightly more often with relatives, friends and colleagues than in the other Nordic countries (Kahma et al. 2014: \$40).

In summary, it can be said that previous studies tend to focus on where commensality is a positive phenomenon from the aspect of social relations, often being associated with conviviality and with celebrations, the family, friends and other groups, which helps those eating together to socialize and maintains their individual well-being, their productivity, etc. There are also some qualitative studies where the attention turns towards the unfavourable aspects of commensality (elimination from the group or hierarchy, the entrenchment of power positions or unbridled alcohol consumption, among other negative aspects).

\section{Research on individual (solo) eating}

Another important aspect of eating studies is research into eating as an individual. As scholars have claimed, eating habits have gradually become more individual in many wealthier countries (Sobal \& Nelson 2003; Fischler 2011; Masson et al. 2018). Not only has the time for eating changed, but often lunch is not eaten at home with one's family but at the workplace (at a cafeteria or at one's work desk) or somewhere in the city, e.g. eating fast food on the run. In some cultures, it is considered acceptable to eat lunch together with one's coworkers or friends, e.g. in South Korea or the US (Moss 2020), while in others it is common for a worker to eat alone. As studies comparing Australian and Japanese ways of eating have shown, this has developed somewhat differently in each culture, where 'the growth of solo eating is shaped by daily negotiation with the following socio-cultural determinants (times, spaces, gender dynamics, and social relations) and their interactions with global trends (e.g., female participation to labour force)' (Takeda 2016). Individual eating is slightly different between our closer northern neighbouring countries: e.g., having 
dinner alone was more typical in Finland than in the other Nordic countries (Kahma et al. 2014: \$40).

In some countries, the social stigma associated with individual eaters remains strong, while in others it is less so. During fieldwork I held an interview with David Vekua, who, while studying business management at Vilnius University, opened an eatery in Vilnius in 2010 along with two fellow nationals from Georgia (Sakartvelo) because he was surprised 'that it was totally normal to have lunch alone in Lithuania. Large groups would gather for lunch in Georgia. One person at the lunch table arouses astonishment and pity. They look like they're unhappy' (Jančys 2014). This is evidence of the social pressure of society on solo-eaters. In a study by P. Pliner and R. Bell that involved students and soldiers, it became evident that a majority of the individuals who were surveyed felt discomfort and a sense of unease when eating alone in public spaces: that is, for many if not most people a solitary meal is a highly undesirable situation and, in some cases, not a meal at all (Pliner and Bell 2009: 174, 184). There are also data showing that eating alone is related to negative dietary results (ibid.: 184), i.e., in Western countries, eating alone has been associated with an increased risk of engaging in unhealthy eating behaviour and diet-related illnesses, such as obesity (Fischler 2011).

Research shows that eating alone provides an opportunity to escape public scrutiny and allows one to eat as one wishes (Pliner and Bell 2009), i.e., to become engaged in the eating process, to maintain a focus on it, to spend as long as one likes eating, not having to wait for others, not making others wait, etc. New research is clearly needed of individual eating experiences during work hours, especially in the somewhat new situation created by the COVID-19 pandemic. Already in the 2010s, various comments in the media have shown that people feel less inhibited about eating alone in public, even though there are cases such as that described by the actor Aistis Mickevičius in an interview: 'in restaurants and cafes I choose more out-of-the-way places to sit, the tables on the fringes, so that I can take the position of the observer, and not the observed' (VMGonline.lt). Introverts, or those who prefer being alone, state that eating alone is an 'infrequent pleasure' (Quora.com 2017 - Grace Gibson).

I would agree with the conclusion reached by Pliner and Bell that there is a lack of information on lay people's views of eating alone, despite the widespread views of academics on the subject (Meiselman 2009: 27): 'it is clear that there is a great deal that we do not know about the causes, correlates, and 
consequences of eating alone' (Pliner and Bell 2009: 184). Much of the existing research about the increasingly common phenomenon of solo-eating stresses that, even though people do eat alone, they do still quite surprisingly eat commensal meals rather often ${ }^{7}$ (Mäkelä. 2009: 43). Thus eating together continues to be an important activity and has important social meanings and functions in young adults' lives (Danesi 2011).

Thus, the few studies of individual eating to have been conducted highlight the negative attitudes towards those who eat alone and the individual eaters own uncomfortable feeling while eating alone in a public space. In this scientific literature, the spread of individual eating is understood as being determined by the pace of life, as well as global economic and social trends. The latest data on individual eating also signals the advantages of this kind of eating, while the challenges that COVID-19 has thrown at us can open new insights on these changes.

\section{Everyday eating among co-workers: together or alone}

When studying the leisure time of groups of co-workers in Vilnius, as mentioned earlier, on the one hand the importance of commensality in maintaining and establishing social relations was highlighted. On the other hand, commensality in workplace collectives depends a great deal on the type of management, the nature of the profession and the social relations that already exist in the collective (Šidiškienè 2019b). Studies by researchers from other countries about commensality in the workplace also draw attention to various cultural and social aspects. A number of studies have been conducted about the positive influence of commensality between co-workers during break times in upholding the organization's culture, strengthening the collective, and so on. Informal social relations are formed and maintained during these kinds of joint gatherings, including when eating together, which contribute to the effectiveness of the organisation (Waldstrøm 2001; Kniffin et al. 2015, Weijs-Perrée 2020: 785). Barbara Plester shows that it is embodied experiences regarding food and drink and the ritual aspects of the experience that create the social, inclusive component, which would appear to be a potent combination, and that it may result in (mostly) positive sense-making and the creation of an organizational culture by employees (Plester, Lo 2011, Plester 2015: 17). Other research reveals that social interaction during work breaks may provide employees with a valuable opportunity to discuss difficult issues, as well as to exchange knowledge about 
their jobs (Waber et al. 2010, citing Wegener et al. 2015: 51). These kinds of social interaction between co-workers help them create strong social groups, enhance work productivity, increase motivation, etc. There are also studies where coffee breaks are viewed as a place, or more precisely a boundary zone, between what is officially considered work and not-work respectively as a way of conceptualizing such social practices where it is possible to integrate different perspectives (Wegener et al. 2015: 52). Such cases have been studied as liminal spaces which employees recursively create at their workplaces, while moving away from their work zone in order to refresh themselves (Lucas and Wright 2015).

The studies just mentioned show that little attention is given to the analysis of individual eating by workers, even though it is precisely during work hours that the employee often has lunch alone or with their co-workers (Kahma et al. 2014: \$40). Individual eating in the workplace can be better revealed by analysing daily eating, i.e., having morning coffee or tea and lunch breaks. The drinking of morning coffee or tea is rarely regulated (except for those organization's where the entire employee work schedule is strictly outlined), while lunch-time in organizations is usually set out in the organization's formal rules (often based on national law). Everyday eating outside the family and not at home has not been widely researched by Lithuanian ethnologists. In her study of the dietary habits of worker's families, Regina Merkiene mentioned that until a cafeteria opened at the factory in Grigiškès in 1964, workers would go home for lunch or bring food from home to eat in their section of the factory. Once the cafeteria opened, half the workers from the same shift would have lunch there at the same time (Merkienè 1966: 132). Antanas Daniliauskas' research on the lives of factory workers in northern Lithuania covered both the interwar and Soviet years. He mentioned that before there was a canteen in the factories, the workers ate food they had brought from home by their machines (Daniliauskas 1970: 123, 1978: 82), and that in the factory from 1907 to 1924 there was a canteen that fed mostly single workers (ibid.: 117; 1978: 79). In the Soviet era too, open self-service canteens were opened just from $1965^{8}$ (ibid.: 136, 1978: 92). Unfortunately, he does not mention whether lunch was consumed together by two or more people or whether people ate alone.

When analysing the leisure time of co-workers in Vilnius, it became evident that the morning coffee-drinking ceremony was very popular during the Soviet period and that is has remained relatively strong since the restoration 
of independence, even though workers are increasingly drinking coffee or tea alone or not practicing such ceremonies at all (Šidiškienè 2019b: 173). During the Soviet period, depending on the situation regarding catering companies at a given workplace and the type of work, co-workers at lunch time in Vilnius would eat together in the cafeteria, or eat snacks at their workplaces that they had brought from elsewhere, while others would go home for lunch (ibid.). Since independence has returned, and depending on the situations just mentioned, co-workers in Vilnius often have lunch together, though individualistic ways of eating have also increased (ibid.: 174). Thus, during the Soviet period, individual acts of having a coffee or lunch in the cafeteria were rare among the Vilnius workers who were surveyed. After independence, more people who ate alone, though organizations also appeared where the practice of a group outing by all employees (usually a smaller collective) to have lunch together at a cafe once a week became common (there were some who would go on such lunches several times a week).

Today in Lithuania, as in many other countries, some organizations (especially those in more remote areas of the city, or who wish to save the time set aside for lunch) try to provide a catering facility (cafeteria, café or the like) or a kitchenette where employees can heat up food brought from home or a store, and eat it there. As respondents surveyed in Vilnius stated, ordinarily employees can have lunch at various public catering facilities if they are located near their workplace, or at home if their workplace is within a reasonable distance. It is usually employees who cannot leave their workplace who eat lunch they have brought with them, i.e., people who work at fire stations, as watch-guards or security guards, sometimes banks or other client service organizations, especially if there are no catering services within their organizations premises. This may, of course, also be a matter of personal choice, when the food offered at cafeterias or cafes is deemed unacceptable, or to save money, or for similar reasons. Some choose to go to a cafeteria if it is located within or not far from the organization. Eating at such places is not necessarily a daily event, especially if there is a larger choice of places to eat near the workplace, when the worker can eat at one place on one day, at another the next day, and so on. Single workers usually go to a café or cafeteria, whereas married workers often bring something prepared to eat from home. Workers go to have coffee, tea or lunch with co-workers with whom they maintain friendly links, or sometimes they go alone if their co-workers are busy or have other plans. 
In order to observe how often co-workers eat in a group or individually, I conducted participant observation on what happens at the cafeteria of one organization which is not publicly advertised (i.e., there is no sign indicating the cafeteria exists), though it is known to the workers of the host organization, as well as by workers from surrounding organizations who go there for lunch. This particular cafeteria is also a convenient place to make this kind of observation because it has two separate entrances, one from the outside, and one from the inside that is only used by the workplace's employees, who have an electronic key-card.

In this activity, I observed clients coming into the cafeteria, most likely co-workers who might have been friends or acquaintances who had met up to come to have lunch together. I recorded whether workers came in to eat alone, in a pair or several in a group. The models were calculated as follows: model 1 for a single client, model 2 for a pair, and model 3 for three or more in a group. I counted these models and drew an average (all the participants in each of the three models were totalled up and an average for each model was calculated). I also made a record of gender, though this did not reveal any particular exceptions in the behaviour of males and females respectively (the workers in the workplace being observed were mostly female). I also compared those clients who came to the cafeteria from elsewhere, i.e., through the outside entrance, and locals who entered through the inside entrance.

My observations showed more local workers coming alone than in pairs or in small groups (on average, during the days of observing, there were twelve cases of single clients, four cases of pairs and four cases of small groups), while workers coming from other organizations came alone (on average eleven cases), in pairs (on average ten cases), and somewhat less often in small groups (on average three cases). Thus, the number of clients arriving alone from other organizations was only slightly lower than workers from the local organization who arrived alone. In total, slightly more workers came to have lunch alone. It was also noticed that among these there were on average two cases of customers ordering takeaway food (usually, several portions at a time), probably from a group of co-workers who ate lunch together at their workplace. When the research was repeated in September, over three days I observed ${ }^{9}$ more cases of people going in to eat alone, both from the local organization and from elsewhere (eight cases each). There were somewhat more cases of customers coming in to eat in pairs or small groups from elsewhere ( 4 and 3.5 cases respectively) 
than from the local organisation (three and one cases respectively). The total distribution of the different models of going to eat regarding both locals and other organizations' co-workers is shown in Figure 1 below:

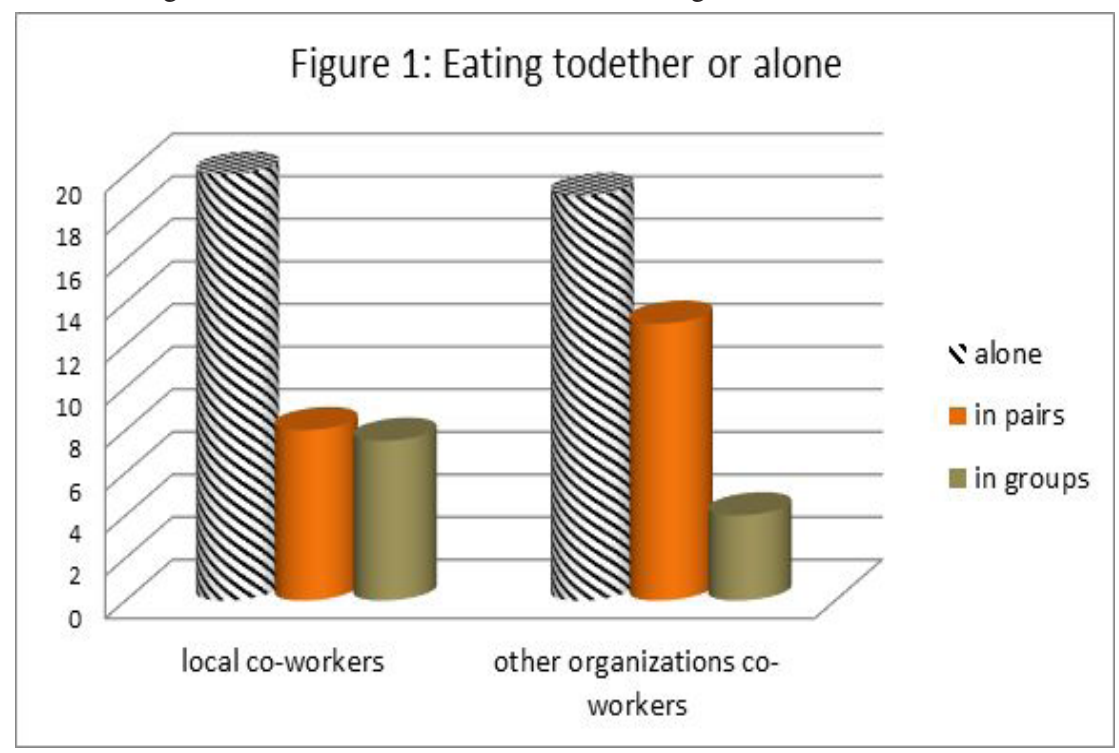

Below in Figure 2 are shown in total the common indicators of employees eating together or individually:

Figure 2: Eating todether or alone

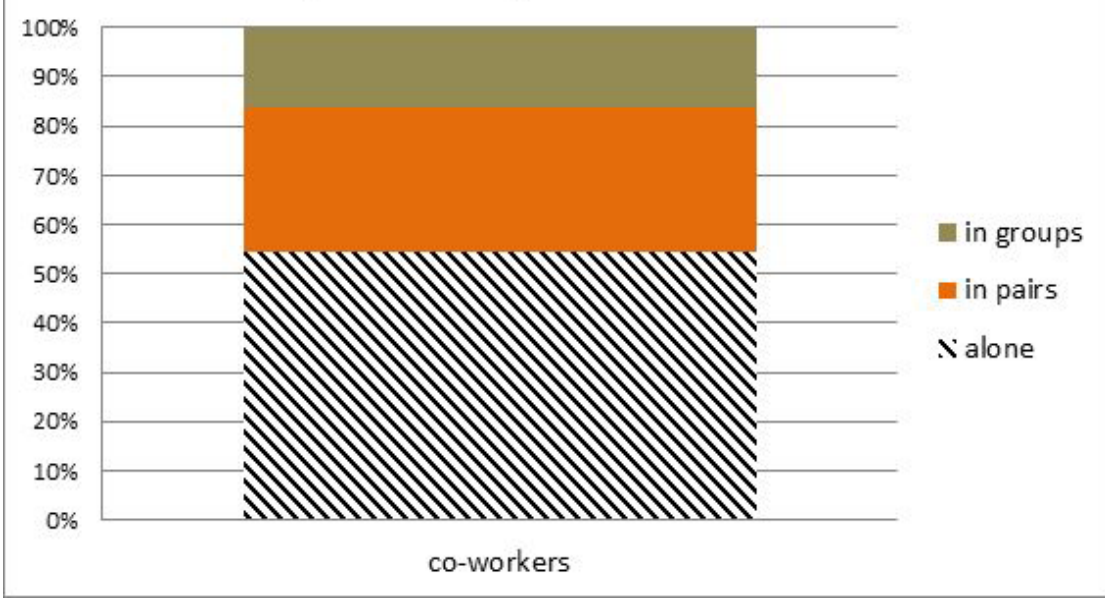


Thus, even though there is a growing trend in individual eating, it is still not dominant among the observed workers.

When observing which tables are chosen by individual eaters and which are taken by small groups, it was noticed that all eaters chose tables close to a window, while tables closer to the counter were chosen last. When there were no more vacant tables, the new arrivals would sit down at a table where there was already one client or a pair. A small group would more often sit at a table at the end of the cafeteria, usually two tables pushed together. There were no real differences in where individual eaters or pairs would choose to sit.

I suggest that analogous research involving repeated observations could provide valuable data for an analysis of the dynamics of the commensality or individual eating habits of co-workers, while observing the same in another country could contribute to comparative research. If the research were to show a growing number of co-workers eating individually, the question arises of how ways of maintaining informal social relations will change?

\section{Conclusion}

This overview of commensality research has shown that a majority of studies confirm the benefits of feasting in terms of maintaining communal feelings among people, as well as the establishment and maintenance of informal links. The concept of feasting or commensality is often associated with conviviality and an elevated mood. Eating together with others usually occurs to mark celebrations or other special occasions. As the leisure-time research of co-workers shows, celebrations are a good pretext for gathering together all or a majority of co-workers. Commensality becomes a favourable time when informal links can be maintained or revived, important matters discussed, etc. In daily life, morning coffee or tea breaks and especially lunch become an expression of individual initiative, a free choice of whether to have lunch with one's co-worker(s) or alone (or perhaps with other people, not co-workers), and whether to create a distance from one's co-workers, maintain relations only at the work level, or to simply have some time alone. Eating with someone else (or others) or as an individual in daily life depends a great deal on one's inner characteristics, i.e., the mutual desire of potential 'co-eaters' to eat together, as well as external circumstances influencing this decision. Individual or solo eating among co-workers in Vilnius is not a rare phenomenon; individual eaters feel comfortable and are not inhibited by others. It would be useful to 
continue observation research in order to determine the dynamics of daily commensality both with co-workers and solo eaters. Perhaps the increase in individual eating will change the ways we establish and maintain informal relations with our co-workers?

\section{Notes}

${ }^{1}$ Eating is an activity that is based on physiological needs and is closely linked to the organization of society and social life (Kjaernes et al. 2007: 511).

2 Žilvytis Šaknys analysed youth gatherings during non-intensive periods of work: their behaviour, gender distribution and the social significance of such gatherings (Šaknys 2001, 2002). Jonas Mardosa's distinguishes and analyses the main types of collective help, the ways in which they were organized and the directions in which they were organized, the social and cultural functions of collective help, and feasting and dietary models during collective help (Mardosa 1997, 2001, 2010).

3 'Usually, in the case of collective help, even those where one day you would help out at one collective help and the next, you would be helped: payment would be in the form of food. [...] The significance of food increased particularly in the twentieth century once the material conditions of the peasants had improved' (Mardosa 1996: 27). Then people would join in on collective help, expecting better food in greater quantities (Mardosa 2010: 12). Moreover, hired workers liked collective help for the better food and feasting it involved, with beer and vodka (Morkūnas 1977: 127).

${ }^{4}$ Commensality is used in the sense of 'eating together', to differentiate it from related activities such as food shopping and cooking (Kniffin 2015: 285).

${ }^{5}$ While the main aspects of commensality, eating alone and similar cases were analysed in the academic literature, the field research was conducted in Vilnius in 2013-2015 using my own survey of 33 respondents. In 2013 two students from the Faculty of History of the Lithuanian University of Educational Sciences (LEU) also joined in the field research, surveying a total of twenty people. In February and September 2020 I conducted participant observation at a Vilnius cafeteria (this observation is presented in the last section of the article), and several respondents were surveyed about eating during work hours with their co-workers.

${ }^{6}$ Scholars are increasingly doubtful whether families in Western countries always ate together at the same table (eating the same meals) (for more, see Meiselman 2009: 26). The fact that this was not characteristic of non-Western ethnic groups is evident from research into migrants eating habits. Helena Tuomainen writes, 'Indeed, the notion of the "family meal" in the literature appears to be ethnocentrically Western: the Ghanaian 


\section{Irma Šidiškienè}

"family meal" is possible without company, or commensality, and [is] in line with kinship and household structures and marital relationships in Ghana’ (Tuomainen 2014: \$54).

${ }^{7}$ In researching commensality from the social perspective, I suggest that the terms 'commensal meals' and 'commensality' should not be taken as synonyms, but discussed further. In terms of diet, 'commensal meals' can refer not just to eating at a common table, but to food prepared in one kitchen with the intention of serving it to all those who have gathered together for it. Usually, 'commensal meals' refer to food prepared at home for friends and family, but I think the term could also be used to refer to food prepared at cafeterias and restaurants where those who have gathered (whether they are family members, or residents of the city, guests, people from the same workplace or participants in another organisation) also eat the same food prepared in the kitchen. Note that researchers have drawn attention to the fact that when used to refer to celebrations at workplaces, use of the term 'commensal meals' can extend to social exclusion, for example, in the case of vegetarians (Arinze 2015: 4, 58). The term 'commensality 'usually means sitting down at one table to eat, however in certain aspects this word meaning can cover all eaters who are sitting down or being in the one room, whether at home or in a public space, such as a restaurant (e.g., in the case of a smorgasbord or buffet).

${ }^{8}$ New research shows that the canteen network had already been expanded during the Second World War, especially in Kaunas (Lugavojus 2016: 135).

${ }^{9}$ The observing took place for one week (over lunch for around an hour) in Vilnius in February, 2020. It was repeated in September.

\section{References}

Arinze, Chinelo 2015. Eating at the Desk: Human Encounters with Workplace Food. Thesis, Georgia State University. Available from http://scholarworks.gsu. edu/ anthro_theses/101 [connection on 2016-06-12]

Danesi, Giada 2011. Commensality in French and German young adults: An ethnographic study. Hospitality \& Society 1: 2, pp. 153-172, doi: 10.1386/hosp.1.2.153_1

Danesi, Giada 2012. Pleasures and stress of eating alone and eating together among French and German young adults. Menu. The journal of Eating and Hospitality Research, 1, pp. 77-91.

Daniliauskas, Antanas 1970. Šiaurès rytu Lietuvos pramonés darbininku materialine kultūra. [Material Culture of Industrial Workers in North-Eastern Lithuania]. Vilnius: Mintis.

Daniliauskas, Antanas 1978. Lietuvos miesto gyventoju materialinè kultūra XX a. [Material Culture of Lithuanian Urban Population in the 20th century]. Vilnius: Mokslas. 
Fischler, Claude 2011. Commensality, society and culture, Social Science Information. 50(3-4), pp. 528-548. DOI: 10.1177/0539018411413963.

Grignon, Claude 2001. Commensality and Social Morphology: An Essay of Typology. In: Scholliers, Peter (ed.). Food, Drink and Identity. Cooking, Eating and Drinking in Europe Since the Middle Ages, pp. 23-33. Oxford, New York: Berg.

Hetherington, Marion M., Anderson, Annie S., Norton, Geraldine N. M. and Newson, Lisa 2006. Situational effects on meal intake: A comparison of eating alone and eating with others. Physiology \& Behavior, 88: 498-505.

Higgs, Suzanne and Thomas, Jason 2016. Social influences on eating. Current Opinion in Behavioral Sciences 9: 1-6.

Jančys, Artūras 2014. Gruzinas ịrodè: Vilniaus stoties rajonas tinka skaniam verslui, 2014-11-09 [Georgian Proves Vilnius Station Area is good for Tasty Business]. Available from: https://www.lrytas.lt/verslas/sekmes-istorijos/2014/11/09/ news/gruzinas-irode-vilniaus-stoties-rajonas-tinka-skaniam-verslui-1402382/ [connection on 2020-08-23]

Kahma, Nina, Mäkelä, Johanna, Niva, Mari and Bøker Lund, Thomas 2014. Associations between meal complexity and social context in four Nordic countries, Anthropology offood [Online], Available from: http://journals.openedition.org/ aof/7666; DOI: https://doi.org/10.4000/aof.7666- last accessed - 29. 06. 2020.

Kjaernes, Unni and Holm, Lotte 2007. Social factors and food choice: consumption as practice. In: Frewer, Lynn and van Trijp, Hans (eds). Understanding consumers of food products. Cambridge: Woodhead publishing.

Kniffin, Kevin M., Wansink, Brian, Devine, Carol M. and Sobal, Jeffery 2015. Eating Together at the Firehouse: How Workplace Commensality Relates to the Performance of Firefighters. Human Performance 28 (4): 281-306. Available from http://dx.doi.org/10.1080/08959285.2015. 1021049 - last accessed 29. 07. 2016.

Lucas, Mike and Wright, Alex 2015. Coffee break: the intertextual production of liminal spaces in the workplace. APROS/EGOS Colloquium 2015, Sub-Theme 19: The Liminality of Organizational Spaces, 9-11 Dec 2015, UTS Sydney, Australia.

Lugovojus, Mantvydas 2016. Kasdienis gyvenimas Kaune vokiečiu okupacijos metais (1941-1944): būstas, maistas ir pramogos. [Daily life in Kaunas during the German Occupation (1941-1944): Housing, Food and Entertainment], Kauno istorijos metraštis 16: 103-165.

Mäkelä, J. 2009. Meals: the social perspective. In: Meiselman, Herbet. L. (ed.) Meals in science and practice. Interdisciplinary research and business applications. Cambridge: Woodhead Publiching Limited; New York: CRC Press LLC, pp. 37-49.

Mardosa, Jonas 1996. Krikščionybès elementai lietuvių 'talkose' [Elements of Christianity in Lithuanian Collective Help (Talka)] Liaudies kultūra 2: 26-30. 


\section{Irma Šidiškienè}

Mardosa, Jonas 1997. Valstiečiu talkos Lietuvoje: XIX a. pabaigoje - XX a. pirmoje puseje. [Peasants Collective Help (Talka). In: Lithuania: late 19th - first half of the 20th century]. Liaudies kultūra 5: 31-34.

Mardosa, Jonas 2001. Talkininkų mitybos modelių kaita XX amžiuje. [Changing Dietary patterns of Collective Helpers in the 20th century]. Lietuvos aukštujų mokyklu mokslo darbai. Istorija 49-50: 77-82.

Mardosa, Jonas 2010. Vaiguviškių talkos XX amžiaus pirmojoje pusejje. [Residents of Vaiguva Collective Help (Talka) in the first half of the 20th century], Lietuvos valsčiai. Vaiguva (Elektroninio serialinio leidinio vyr. redaktore ir sudarytoja Ieva Švarcaitè [Chief of Electronic Serial Publication editor]) ISSN 2029-0799, visatekstèje svetainèje [full text site] www.llt.lt.

Marovelli, Brigida 2019. Cooking and eating together. London: Food sharing initiatives as collective spaces of encounter. Geoforum 99: 190-201.

Masson, Estelle, Bubendorff, Sandrine and Fraïssé, Christèle 2018. Toward new forms of meal sharing? Collective habits and personal diets. Appetite 123: 108-113. DOI: 10.1016/j.appet.2017.12.006.

Meiselman, H. L. 2009. Meals in science and practice: an overview and summary. In: Meiselman, Herbet L. (ed.). Meals in Science and Practice-Interdisciplinary Research and Business Appliations. Cambridge: Woodhead Publiching Limited; New York: CRC Press LLC, pp. 16-36.

Merkienè R[egina] 1966. Grigiškių bandomojo popieriaus kombinato darbininkų buitis ir kultūra. (3. Maistas). [The Life and Culture of the Workers of the Grigiškès Pilot Paper Mill. (3. Food)]. Lietuvos TSR Moksly akademijos darbai. Serija A 1(20): 121-139.

Morkūnas, Vitalis 1977. Nuo tamsos ligi tamsos (Žemès ūkio darbininku buitis Lietuvoje 1919-1940. [From Darkness to Darkness. The Life of Agricultural Workers in Lithuania 1919-1940].Vilnius: Mokslas.

Moss, Laura. January 17, 2020. Whats the Big Deal About Eating Alone?. Treehugger.com Available from https://www.treehugger.com/whats-the-big-deal-about-eatingalone-4862471 - last accessed 20. 09. 2020.

Nahum-Claudel, C. 2016. Feasting. In: Stein, F., Lazar, S., Candea, M., Diemberger, H., Robbins, J., Sanchez, A. and Stasch, R. (eds.). The Cambridge Encyclopedia of Anthropology. Available from http://doi.org/10.29164/16feasting

Nezabitauskis Liudvikas 1935. Talkos žemaičiuose. [Talka (Collective Helps) in Samogitia]. Tautosakos darbai 1: 112-127.

Nowicka, Magdalena 2020. Fantasy of Conviviality: Banalities of Multicultural Settings and What We Do (Not) Notice When We Look at Them. In: Hemer, Oscar, Povrzanović Frykman, Maja and Ristilammi, Per-Markku (eds.). Conviviality at the Crossroads. The Poetics and Politics of Everyday Encounters. Palgrave 
Macmillan, pp. 1-14. https://doi.org/10.1007/978-3-030-28979-9 - last accessed 20. 06. 2020.

Plester, Barbara 2015. Ingesting the organization: The embodiment of organizational food rituals. Culture and Organization 21 (3): 251-268.

Plester, Barbara and Lo, Kevin 2011. 'Let's do lunch!' An embodied perspective of organizational food rituals and practices. Australian and New Zealand Academy of Management (ANZAM).

Pliner, P. and Bell, R. 2009. A table for one: the pain and pleasure of eating alone. Meals in science and practice. In: Meiselman, Herbet L. (ed.) Interdisciplinary research and business applications. Cambridge: Woodhead Publiching Limited; New York: CRC Press LLC, pp. 169-189.

Polivy, Janet 2017. What's that you're eating? Social comparison and eating behavior. Journal of Eating Disorders 5(18): 1-5.

Polivy, Janet and Pliner, Patricia 2015. 'She got more than me.' Social comparison and the social context of eating. Appetite 86: 88-95.

Quora. com 2017. Available from https://www.quora.com/Do-you-enjoy-eating-aloneespecially-at-restaurants-Why-or-why-not - last accessed 20. 09. 2020.

Šaknys, Žilvytis Bernardas 2001. Kalendoriniai ir darbo papročiai Lietuvoje XIX a. pabaigoje - XX a. pirmojoje pusèje. Jaunimo vakarèliai. vakarèliai [Lithuanian Calendar and Work Customs in the late 19th - first half of the 20th century. Youth Parties]. Vilnius: Diemedis.

Šaknys, Žilvytis 2002. Jaunimo neintensyvaus darbo savitumai Lietuvoje (XIX a. pabaiga - XX a. pirmoji pusè) [Specific features of non-intensive youth work in Lithuania (end of the 19th-first half of the 20th cc.) ]. Lituanistica 1(4), p. 42-56.

Šidiškienè Irma 2017. Neformalių kaimo ir miesto darbo bendrijų sąsajos socialinių santykių aspektu, [The Relationship between Informal Rural and Urban Working Communities in the aspects of Social Relations]. LOGOS liepa-rugsejis (92): 84-91.

Šidiškienė Irma 2018. Šventès, progos miesto bendradarbių kultūroje. Vilniaus ir Sofijos atvejai. [Celebrations and Occasions in the Culture of the Urban Co-worker's. The Cases of Vilnius (Lithuania) and Sofia (Bulgaria)]. Lituanistica 2(112): 135-150

Šidiškienè Irma 2019a. Šventès ir bendradarbių kultūra Vilniuje bei jo apylinkèse, [Celebrations and Co-worker Culture in Vilnius and its Environs]. RES HUMANITARIAE XXV, p. 77-94.

Šidiškienė Irma 2019b. Bendradarbių laisvalaikis. Miestiečių bendrijų formavimasis ir kultūrinè raiška. [Co-workers' Leisure Time. The Formation and Cultural Expression of Urban Communities]. In: Paukštytė-Šaknienè, Rasa; Šidiškienè, Irma and Šaknys, Žilvytis (eds.). Vilniečiu socialinè squeika ir kultūrinè raiška: 
laisvalaikis, šventès ir ritualai. Ritualai. [Social Interaction and Cultural Expression of Vilnius Residents: Leisure Time, Celebrations and Rituals], Vilnius: Lietuvos istorijos institutas, pp. 112-194, 289-296.

Sobal, J. and Nelson, M. K. 2003. Commensal eating patterns: A community study. Appetite 41(2): 181-190.

Spence, Charles 2016. Gastrodiplomacy: Assessing the role of food in decision-making. Flavour 5(4): 1-16. DOI 10.1186/s13411-016-0050-8

Takeda, Wakako 2016. Reconsidering Individualisation of Eating: a cross-cultural analysis on determinants of commensality and solo-eating. A thesis submitted for the degree of Doctor of Philosophy at the Australian National University.

Tan, Chee-Be 2015. Commensality and the Organization of Social Relations. In: Kerner, Susanne, Chou, Cynthia and Warmind, Morten (eds.). Commensality. From Everyday Food to Feast. Bloomsbury Academic: Bloomsbury Publishing

Tuomainen, Helena 2014. Eating alone or together? Commensality among Ghanaians in London. Anthropology of food. http://aof.revues.org/7718 last accessed 03.08. 2016.

van Gennep, Arnold 1960. The Rites of Passage. Chicago: The University of Chicago Press. VMGonline.lt n. d. Geriausios vakarienès vietos pagal aktorių Aistị Mickevičių, [Best Places to Dine by Actor Aistis Mickevičius]. Available from https://www. vmgonline.lt/post/kur-pavalgyti-geriausios-vakarienès-vietos-pagal-aktoriųaistį-mickevičiuc. - last accessed 21. 09. 2020.

Waber, Benjamin N., Olguin Olguin, Daniel, Kim, Taemie and Pentland, Alex 2010. Productivity Through Coffee Breaks: Changing Social Networks by Changing Break Structure (January 11, 2010). Available at SSRN: https://ssrn.com/abstract=1586375 -last accessed 21.09. 2020.

Waldstrøm, Christian 2001. Informal Networks in Organizations - a literature review. DDL Working Paper No. 2. The Aarhus School of Business.

Wegener, Charlotte, Meier, Ninna and Ingerslev, Karen 2015. Drinking coffee at the workplace. Work or leisure?. Academic Quarter 11: 47-57.

Weijs-Perrée, Minou, Appel-Meulenbroek, Rianne and Arentze, Theo 2020. Location Type Choice for Face-to-Face Interactions in Business Centers. Environment and Behavior 52(7): 761-794. DOI: 10.1177/0013916518819715

Yiengprugsawan, Vasoontara, Banwell, Cathy, Takeda, Wakako, Dixon, Jane, Seubsman, Samang and Sleigh, Adrian C. 2015. Health, Happiness and Eating Together: What Can a Large Thai Cohort Study Tell Us?. Global Journal of Health Science 7 (4): 270-277. 
Irma Šidiškienè is a researcher in the Department of Ethnology and Anthropology at the Lithuanian Institute of History. Main areas of research interest: expression of nationality, cultural heritage; urban ethnology and anthropology; social and cultural expression of co-workers'; history of ethnology and anthropology. 